\title{
Current Status of Parasite Infections in Indonesia: A Literature Review
}

\author{
Juyoung Lee ${ }^{1}$, Jae-Sook Ryur,** \\ 'Department of Malay-Indonesian Interpretation and Translation, Hankuk University of Foreign Studies, Yongin 17035, Korea; \\ ${ }^{2}$ Department of Environmental Biology and Medical Parasitology, Hanyang University College of Medicine, ${ }^{3}$ Department of Biomedical Science, \\ Graduate School of Biomedical Science \& Engineering, Seoul 04763, Korea
}

\begin{abstract}
Indonesia and South Korea have become inseparable in various respects since the 2 countries established diplomatic relation in 1973. Indonesia is a tropical region that stretches across the equator, comprised of 5 main islands (Java, Kalimantan, Sumatra, Sulawesi, and Papua) and 4 archipelagoes (Riau, Bangka Belitung, Nusa Tenggara, and Maluku). As most population of Eastern Indonesia (Sulawesi, Papua and Nusa Tenggara \& Maluku) live in poor areas, it is expected that there will be many parasites. Nevertheless, little is known about the status of parasites in Indonesia. This study examines the prevalences of malaria and lymphatic filaria, which are prevalent in Indonesia, as well as those of soiltransmitted-helminths (STH). As a result, the Plasmodium falciparum and $P$. vivax case loads are almost equal. The current prevalence of $P$. vivax is uniformly low $(<5 \%)$ in all age groups and annual parasite incidence (API) showed decreasing tendency as 0.84 per 1,000 population in 2016. However, more than 65 million people still live in malaria epidemic regions. Lymphatic filariasis remains an important public health problem and 236 cities were classified as endemic areas in 514 cities/districts in 2017. It is difficult to ascertain the current prevalence rate of STH in Indonesia, although West Sumba and Southwest Sumba in East Nusa Tenggara reported prevalence rate of more than $20 \%$. The study also considers the (sero) prevalences of other parasites identified in Indonesia. This report should be useful not only to parasitologists but also to travelers and people with business in Indonesia.
\end{abstract}

Key words: Indonesia, parasite, prevalence, malaria, filaria, soil-transmitted helminths

\section{INTRODUCTION}

The Republic of Indonesia (hereafter Indonesia) is the largest archipelago nation in the world. It consists of 16,056 islands covering a land area of $1,916,862.20 \mathrm{~km}^{2}$. Its population was estimated at approximately $261,890,900$ in 2017 [1].

It comprises 5 main islands and four archipelagoes, namely, the islands of Java, Kalimantan, Sumatra, Sulawesi and Papua, and the archipelagoes of Riau, Bangka Belitung, Nusa Tenggara and Maluku (Fig. 1). The Wallace line separates Western Indonesia (Java, Kalimantan, Sumatra and Riau \& Bangka Belitung) and Eastern Indonesia (Sulawesi, Papua and Nusa Tenggara \& Maluku). As most of population of Eastern Indonesia live in poor areas, it is expected that there will be many parasites.

\footnotetext{
- Received 6 February 2019, revised 28 May 2019, accepted 30 May 2019.

*Corresponding author (jsryu@hanyang.ac.kr)

(c) 2019, Korean Society for Parasitology and Tropical Medicine

This is an Open Access article distributed under the terms of the Creative Commons Attribution Non-Commercial License (http://creativecommons.org/licenses/by-nc/4.0) which permits unrestricted non-commercial use, distribution, and reproduction in any medium, provided the original work is properly cited.
}

Nevertheless, little is known about the status of parasites in Indonesia.

Indonesia has the largest economy in Southeast Asia, and is the only member of the G20 in the Association of Southeast Asian Nations (ASEAN). In recent years the country has become increasingly important to South Korea because of the "New Southern Policy" promoted by the government of South Korea. The relationship between Indonesia and South Korea has become inseparable in various respects since the 2 countries established diplomatic relations in 1973, and especially since the creation of the special strategic partnership in 2017. For instance, 31,091 citizens of South Korea live in Indonesia and 45,328 citizens of Indonesia live in South Korea [2,3]. In addition, South Korea was the fifth largest trading partner of Indonesia, and Indonesia the 10th investment partner of South Korea in 2016. Furthermore, on average of 350,000 citizens of South Korea visit Indonesia and 250,000 citizens of Indonesia visit South Korea each year.

In spite of its close relationship, Indonesia is still regarded as an unfamiliar country by the people of South Korea, espe- 


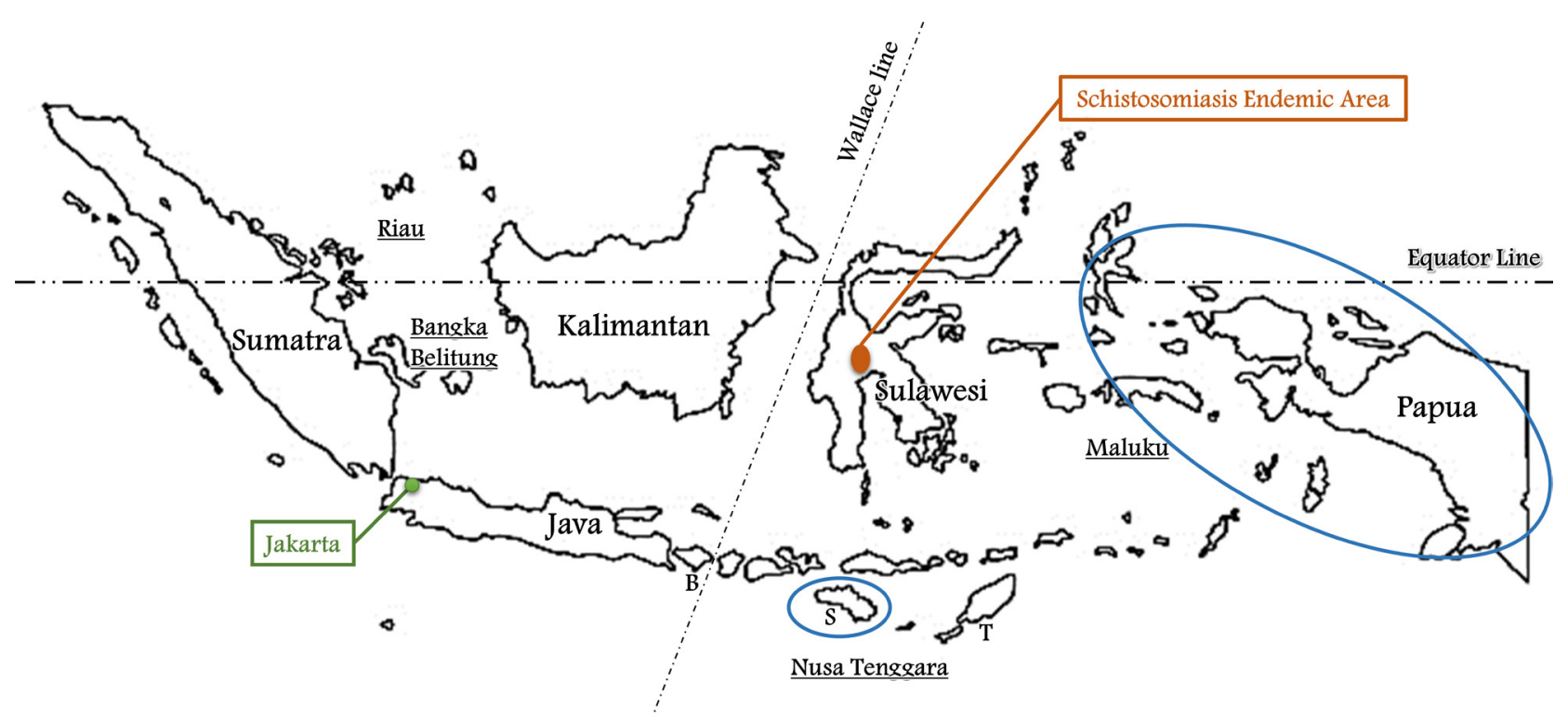

Fig. 1. Indonesia is comprised of five main islands, namely, Java, Kalimantan, Sumatra, Sulawesi, and Papua and four archipelagoes, Riau, Bangka Belitung, Nusa Tenggara, and Maluku. The Wallace line separates Western and Eastern Indonesia. Schistosoma japonicum is found only in Central Sulawesi. The blue circle is the area with the highest annual parasite incidence (API) of malaria. B, Bali; S, Sumba; T, Timor.

cially in relation to the medical sector, and the parasites of Indonesia are not well known in South Korea. Given the prominence of parasites in Indonesia, it is important to investigate and summarize their impact in Indonesia to help Koreans become more familiar with them.

Below we describe the current status of prevalent parasites such as Plasmodium spp., lymphatic filaria, soil-transmitted helminths, cysticercosis/Taenia spp., Schistosoma japonicum and Toxoplasma gondii, all of which cause significant disease in Indonesia. Other parasites whose existence is known in Indonesia may be listed as follows: in protozoa; Entamoeba histolytica, Giardia lamblia, Blastocystis hominis, Cryptosporidium sp., $\mathrm{Cy}$ clospora cayetanensis, Trichomonas vaginalis; in Nematodes; Trichinella spiralis, Capillaria philippinensis, Strongyloides stercoralis, Anisakis, Toxocara canis; in Trematodes; Fasciolopsis buski, Echinostoma sp.; in Cestodes; sparganum, Echinococcus granulosus, Hymenolepis nana.

For this study, we identified published studies using automated data base searches of the National Library of Medicine's PubMed and further manual searching was done using Google Scholar. Also, the data from the Ministry of Foreign Affairs \& Ministry of Justice in Republic of Korea, the Statistics Indonesia and the Ministry of Health Republic of Indonesia $(\mathrm{MoH}$ RI) were searched and utilized.

\section{MALARIA}

Malaria has received much attention from the public health sector in most tropical countries due to the difficulties in eliminating the disease, and the fluctuations in annual cases. In 2015-2016, malaria cases increased by 5 million, spread over 91 countries across the globe, and it was responsible for 445,000 deaths in 2016 [4]. It is one of the health problems given priority by the Ministry of Health Republic of Indonesia. Indonesia has many features that make it vulnerable to malaria: it is an equatorial country with malaria-receptive Anopheles mosquitoes; a large, dispersed population ( $>260$ million and $>5,000$ inhabited islands); high internal migration; socioeconomic inequality; and decentralized governance $[5,6]$.

Five species of Plasmodia are present; Plasmodium falciparum, P. vivax, P. malariae, P. ovale, and P. knowlesi. The 25 known anopheline vectors transmitting malaria in Indonesia are found in plantations, aquaculture ponds and in villages. They are; Anopheles aconitus, An. balabacensis, An. bancroftii, An. barbirostris, An. farauti, An. flavirostris, An. karwari, An. kochi, An. koliensis, An. leucosphyrus, An. maculatus, An. nigerrimus, An. parangensis, An. punctulatus, An. sinensis, An. subpictus, An. sundaicus, An. tessellatus, An. vagus, An. lebifer, An. ludlowi, An. minimus, An. umbrosus, An. peditaeniatus, and An. annullaris [7]. 
According to Elyazar et al. [8], the median prevalence rates of four Plasmodium spp. between 1900 and 2008 were: P. falciparum 5\% (range: 0.03-82\%); P. vivax 3\% (range: 0.03-70\%); $P$. malariae $2 \%$ (range: $0.05-53 \%$ ) and $P$. ovale $0.2 \%$ (range: 0.07 $4.9 \%$ ). The prevalences of these four Plasmodia were higher in Eastern Indonesia than in the rest of the country. However, $P$. knowlesi was found in four out of 22 people living in Kaliman$\tan [8,9]$.

Most Indonesian malarial infections (83\%) occur in Papua, West Papua and East Nusa Tenggara [10], and the Plasmodium falciparum and Plasmodium vivax caseloads are almost equal. The current prevalence of $P$. vivax (in peripheral blood smears) is uniformly low $(<5 \%)$ in all age groups; it increases somewhat during the seasonal rains, and probably at least several million Indonesians suffer acute vivax malarial infections each year [11]. In terms of rates of malaria by occupation, residential area and age group, the rate among farmers, fishermen and workers $(7.8 \%)$ is higher than among civil servants (4.7\%). Rural areas (7.1\%) have a higher prevalence than cities (5.0\%). Infection rates are similar at all ages; in 2013 the lowest infection rate in the age group between 65 and 74 was $4.8 \%$, and the highest infection rate in the age group between 25 and 34 was 6.6\% [12]. Malaria is known to cause severe maternal anemia, fetal loss and low birth weight. Nevertheless, about 6.4 million pregnancies are exposed to malaria annually in Indonesia [13].

In 2009 the Ministry of Health Republic of Indonesia announced a plan to reach the pre-elimination stage by 2020 and to be free of malaria transmission by 2030 [14]. Indonesia's rapid progress in the past decade has resulted in more than half of its districts being officially declared malaria-free [5,15]. Between 2007 and 2016, annual parasite incidence (API, along with the blood slide positivity rate) fell threefold, from 2.89 to 0.84 per 1,000 population [10]. API continuously decreased from $2011(1.75)$ to 2016 (0.84) with APIs of $1.75,1.69,1.38,0.99,0.85$, and 0.84 . Nonetheless, the following provinces had high APIs: Papua (45.85), West Papua (6.79), East Nusa Tenggara (5.41), Maluku (3.95), and North Maluku (2.44) in 2016 (Fig. 1). In contrast, malaria infection was reduced by more than $80 \%$ in Jakarta, Bali, East Java, West Java, Central Java, West Sumatra and Yogyakarta. Malaria has been completely eliminated in Jakarta and Bali [16].

However, despite the government's efforts, 25 percent of the population (more than 65 million) still live in malaria epidemic regions [17]. Obstacles faced in eliminating transmis- sion of $P$. vivax include: the relapse behavior of $P$. vivax in Indonesia, which is generally believed to be the Southeast Asian/ West Pacific pattern represented by the single strain designated Chesson [18]. The relapse behavior of that strain may be summarized as rapid and frequent, with most first relapses occurring at around day 21 post-patency of the primary parasitemia; $75 \%$ or more relapses before day 28 , and up to 5 relapses over 2 years are the rule [19]. Another greatest impediment to the control of vivax malaria in Indonesia is primaquine toxicity in glucose-6-phosphate dehydrogenase-deficient (G6PDd) patients. This highly diverse X-linked disorder is prevalent among many of Indonesia's hundreds of ethnic groups. For this reason, the WHO recommends G6PD testing prior to administration of PQ for radical cure of P. vivax [20].

In addition, the increase of drug-resistant malaria is impeding appropriate treatment. The Ministry of Health Republic of Indonesia recommends the ACT (artemisinin-combined therapy), DHA-PP (dihydroartemisinin-piperaquine), as first-line treatment for acute attacks because of the high prevalence of chloroquine-resistant $P$. vivax. Also, the guidelines offer a warning regarding the signs and symptoms of acute hemolytic anemia in patients receiving primaquine (and other drugs), and recommend a weekly dose of $0.75 \mathrm{mg} / \mathrm{kg}$ for 8-12 weeks [21]. There are 2 options for first-line treatment of uncomplicated falciparum malaria. The first is a combination of artesunate (AS) and amodiaquine (AQ) taken orally for 3 days, with a single dose of primaquine $(\mathrm{PQ})$ as a gametocytocide on the first day $(\mathrm{AS}+\mathrm{AQ}+\mathrm{PQ})$. The alternative first-line treatment is the combination of dihydroartemisinin (DHA) and piperaquine (PP) taken orally for 3 days, with a single dose of PQ given on the first day (DHA+PP+PQ) [8].

\section{LYMPHATIC FILARIASIS}

Lymphatic filariasis (LF) is an important public health problem facing low- and middle-income countries across the world. More than 120 million people worldwide are directly affected by the disease, and over a billion people are at risk of infection $[22,23]$. LF causes permanent malformation of several body parts and is one of the most important infectious causes of permanent limb disability worldwide. The disabilityadjusted life year (DALY) of LF is the highest of all tropical diseases [24]. LF is also a major cause of poverty due to loss of productivity, and eventually becomes an economic burden on family and society [25]. 
In Indonesia, LF remains an important public health problem. The microfilaremia prevalence in 1980 in Indonesia was reported to be $19.5 \%$, and it was reduced to $4.7 \%$ by 2014 due to the efforts of the Ministry of Health Republic of Indonesia [26].

Nonetheless, 236 cities were classified as endemic areas in 514 cities/districts. Mass Drug Administration (MDA) was still progressed in 152 cities in 2018. It was estimated that a population of about 62 million required MDA in $2016[27,28]$. The number of chronic filariasis was estimated at 12,677 in 2017. The provinces showing many chronic filariasis are as followings: Papua $(3,047)$, East Nusa Tenggara $(2,864)$, West Papua $(1,244)$, West Java (907) and Aceh (591) in Sumatra. In contrast, North Kalimantan (11), West Nusa Tenggara (14) and Bali (18) showed small number of filariasis [27].

Indonesia is the only country in the world with 3 types of LF parasite: Wuchereria bancrofti, Brugia malayi, and Brugia timori. B. malayi is more widely distributed than $W$. bancrofti and B. timori, and has been found on Sumatra, Kalimantan, Sulawesi and Maluku. Furthermore, W. bancrofti and B. malayi each have several distinct ecotypes with different vector species and ecology. This variability leads to varied transmission dynamics and responses to intervention [28,29]. Nocturnal $B$. malayi is transmitted by An. barbirostris, which lives in paddy fields, and nocturnal subperiodic B. malayi is transmitted by Mansonia spp. Microfilaria in blood are mostly found in night. However, non-periodic B. malayi is transmitted by Mansonia uniformis and $\mathrm{M}$. bonneae, and their microfilariae in blood are also found in day and night [26]. Nocturnal Brugia timori is found in limited areas of Eastern Indonesia such as Timor, Flores, Rote, the Alor islands and the small islands of East Nusa Tenggara and Southeast Maluku. The vector (transmitter) of B. timori is An. barbirostris. However, urban Wuchereria bancrofti is transmitted nocturnally by Culex quinquefasciatus, which lives in domestic waste water and has been found in urban areas such as Bekasi, Tangerang, Pekalongan and Lebak in Java. In contrast, rural W. bancrofti is found outside Java, particularly in Papua and East Nusa Tenggara, and is transmitted nocturnally by Culex sp. and Anopheles sp. (An. gambiae, An. funestus, An. scapularis) [26].

In 2000, the Global Program to Eliminate LF (GPELF) was established by the World Health Organization, with the target of eliminating LF by 2020 [30]. GPELF uses a 2-pronged approach, combining MDA for all those eligible in at risk populations [22], with assistance for those with lymphedema and elephantiasis to reduce LF morbidity and suffering [30]. The MDA uses a single dose of diethylcarbamazine citrate (DEC, 6 $\mathrm{mg} / \mathrm{kg}$ body weight) and albendazole (fixed dose $400 \mathrm{mg}$ ). The aim of MDA is to decrease the microfilaria rate and the transmission rate of LF [31]. However, DEC does not kill adult worms, and, therefore, MDA must be implemented annually to the entire eligible population for 5 or more consecutive years, until the adult worms either die or stop producing microfilaria [32].

\section{SOIL-TRANSMITTED HELMINTHS}

Neglected tropical diseases (NTDs) mostly affect people who live in extreme poverty; these diseases are also known to increase poverty even further because of their chronic and debilitating effects [33,34]. The World Health Organization recognizes 17 major parasitic and related infections as NTDs $[34,35]$. Of these 17 NTDs 11 are parasitic diseases, namely the helminth diseases, cysticercosis/taeniasis, dracunculiasis (guinea-worm disease), echinococcosis, foodborne trematodiases, lymphatic filariasis, onchocerciasis (river blindness), schistosomiasis and soil-transmitted helminthiases (STH), and the protozoan diseases, Chagas disease, human African trypanosomiasis (sleeping sickness) and leishmaniasis.

There are 4 main species of STH: Ascaris lumbricoides, Trichuris trichiura and the hookworms (Ancylostoma duodenale and Necator americanus) [36]. Pullan et al. [37] estimated that in 2010, 438.9 million people globally were infected with hookworm, 819.0 million with A. lumbricoides and 464.6 million with T. trichiura. Southeast Asia (SEA) is the region with the highest reported prevalence of STH infection in recent decades [37]. Indonesia is the largest country and although it has the greatest economic power in SEA, it contains more than half of the 200 million poorest SEA citizens, with $43.3 \%$ of the population (about 109.8 million) living on less than US\$3.20 per day [34,38]. A national survey carried out in 2008 reported a regional prevalence of STH infection of up to $61 \%$ [39]. Hotez et al. [40] reported that Indonesia has the greatest number of cases of ascariasis and trichuriasis (more than 90 million cases of each) as well as of hookworm (60 million).

It is difficult to ascertain the current comprehensive prevalence rate of STH in Indonesia. It is known that the rate in children is higher than in adults due to poor personal hygiene. The average prevalence of STH infection in school age children between 2002 and 2009 was reported to be 31.8\% [41], while 
the rate of STH infection in children under 5 in Tegal City of Central Java Province in 2010 was about 12.3\% [42]. Hotez et al. [34] reported numbers of estimated intestinal helminth infections of 16.9 million in pre-school age children and 43.5 million in school-age children in 2012 [34,43].

East Nusa Tenggara (Indonesian: Nusa Tenggara Timur, NTT) is the southernmost province of Indonesia and the third poorest province. It consists of more than 500 islands, the largest ones being Sumba, Flores, and the western part of Timor. The Ministry of Health Republic of Indonesia reported prevalence rate of more than 20\% in West Sumba (in 2011) and Southwest Sumba (in 2013) [41,44]. Kalena Rongo village, the poorest village in Southwest Sumba had an even higher prevalence of STH: A. lumbricoides 65.8\% (279/424), T. trichiura $60.4 \%$ (256/424), hookworms 53.5\% (227/424) in 2014 [45].

However, Indonesia has implemented MDA for deworming, and provides albendazole treatment to school children biannually [46]. MDA has led to a significant reduction in prevalence of STH. Education is an important route to transforming participants' behavior, but behavioral changes are difficult to obtain in poor and remote areas, especially when the people are poorly educated. Therefore, $\mathrm{WHO}$ recommends mass treatment every 6 months for at least 5 years; in that way the worms could be controlled without altering the environment and behavior [47].

\section{CYSTICERCOSIS/TAENIASIS}

Cysticercosis/Taeniasis is one of the 17 major NTDs identified by the WHO [35]. The majority of the population of Indonesia is Muslim (87.2\%), whereas the remaining $12.8 \%$ consists of Christians, Buddhists, Hindus and others. Christian populations are the majority in certain districts in several Province of Indonesia such as East Nusa Tenggara, North Sulawesi, Papua and North Sumatra. By contrast, in Bali Province the majority of the inhabitants are Hindus (83.5\%) [48]. Usually, taeniases due to the ingestion of uncooked meat are in general rare in Indonesia, since Muslims usually do not eat uncooked meat. Nonetheless, three Taenia species affecting humans have been reported in Indonesia: T. solium mainly in Papua and Bali, T. saginata in Bali, and T. asiatica (a hybrid-derived descendant of T. asiatica and T. saginata) in Samosir Island and Simalungun District, North Sumatra [49,50]. T. saginata is rather common in Bali where local people consume uncooked beef dish (beef lawar) as a traditional local food [49].
Taeniasis and neurocysticercosis (NCC) have also been reported from Lampung, Jakarta, East Java, East Nusa Tenggara, West Kalimantan, East Kalimantan, North Sulawesi, South Sulawesi, and South East Sulawesi [49,52]. It is believed to be decreasing in Bali due to improvements in household sanitation and pig husbandry, following sustained public health education campaigns and economic progress [53]. Recently, Swastika et al. [54] reported 20 cases of T. solium and 39 cases of $T$. saginata in Karangasem and Gianyar town in Bali, respectively.

In Papua, taeniasis/cysticercosis cases due to T. solium were first reported from Paniai district in 1973. Movement of people from the endemic district (Paniai) to other districts appears to have spread the parasite to other districts in Papua. In 2009, Salim et al. [55] reported prevalence of cysticercosis in four central highland districts of Papua; the Jayawijaya (20.8\%) and Paniai districts (29.2\%) showed higher rate compared with 2\% in the other 2 districts (Pegunungan Bintang and Puncak Jaya). Among 71 pigs in 5 villages from Jayawijaya, 50 pigs (70.4\%) were seropositive [56]. Analysis of dog sera revealed 7 of 64 dogs $(10.9 \%)$ were highly positive. The 2 seropositive dogs had cysticerci of T. solium in their brain and heart. Therefore, cysticercosis has been confirmed in humans, pigs and even dogs [57]. Survey in 2012 in Jayawijaya, revealed lower prevalence rate compared with those of 2009; 8.3\% of humans and $19 \%$ of pigs [49]. Nonetheless, lifestyle, religion, and socioeconomic aspects were known to be important issues in the perpetuation and enhancing the endemicity of $T$. solium taeniasis and cysticercosis in Papua [58]. Therefore, it has been very difficult to control taeniasis/cysticercosis in Papua [49].

\section{SCHISTOSOMA JAPONICUM}

In Indonesia, schistosomiasis japonicum has been identified in 3 isolated areas of Central Sulawesi Province, namely Lindu, Napu, and Bada Valleys (Fig. 1). The disease has been a public health problem in the Lindu and Napu Valleys for more than 70 years, since the disease was first discovered in Indonesia [59]. Bada Valley has been identified as a new schistosomiasis endemic area in 2008 [60]. Lindu Valley is at an altitude of 950-1,100 m above sea level. Its total area is approximately $50 \mathrm{~km}^{2}$ and consists of 7 villages. Napu Valley is located in the sub-district of North Lore, Poso, and is at the same altitude, but has a much larger endemic area (approximately $7,500 \mathrm{~km}^{2}$ ) comprising 17 endemic villages. The Bada Valley consists of 6 villages situated south of the Napu-Besoa Valley. 
The initial field survey of Schistosoma japonicum infection, carried out in 1940, indicated a prevalence of 56\% of schistosomiasis in 3 villages in Lindu Valley. A study of the epidemiology of the disease and ecology of the intermediate host, and pilot control trials, were conducted since 1971. These identified Oncomelania hupensis lindoensis as the intermediate snail host [61].

In addition, Carney et al. [62] found that the parasite infected not only humans but also 13 other mammalian species living in the surrounding areas, including wild rodents, wild pigs, wild deer, wild shrews, wild civet cats, cattle, water buffalo, horses and dogs in the endemic areas $[62,63]$. However, the role of livestock and wild animals in the epidemiology and transmission of schistosomiasis in Central Sulawesi remains unclear. Human, rat and snail surveys were conducted in 2008-2011. The data from human surveys showed that the prevalence of schistosomiasis fluctuated between $0.3 \%$ and 4.8\% in Napu Valley, and between $0.8 \%$ and 3.6\% in Lindu Valley. Rats are known to be good indicator animals for identifying schistosomiasis transmission [64]. During that period the percentage of infected rats fluctuated between $7.9 \%$ and 18.2\% in Napu Valley and between 6.7\% and 9.8\% in Lindu Valley. The snail surveys showed that the percentages of infected snails fluctuated between $1.7 \%$ and $4.0 \%$ and between $1.8 \%$ and $3.6 \%$ in Napu Valley and Lindu Valley, respectively. The total rates in humans in Bada Valley were 0.8\% $(9 / 1,067)$ and 5.9\% in 2008 \& 2010, respectively [60]. Fortunately, Schistosoma infection has gradually decreased, and the rate has been low recently. Infection rates in Lindu Valley were $0.71 \%$ and 0.85\% in 2013 and 2017, respectively, and in Napu Valley, $2.24 \%$ and $0.65 \%$, respectively. Bada Valley had a rate of $0.97 \%$ in 2017 [65]. Thus, the infection rates in the 3 endemic valleys were less than $1 \%$ in 2017.

In order to maintain the low prevalence of schistosomiasis in endemic areas, a number of routine control activities were continued after the CSIADC (Central Sulawesi Integrated Area Development and Conservation) project of 1999-2005. These included human and animal stool examinations every 6 months, rat and snail surveys, selective human treatment with a single dose of praziquantel ( $60 \mathrm{mg} / \mathrm{kg}$ body weight), snail control and community health education, particularly for school children and farmers. This approach was able to slowly reduce environmental contamination, thereby lowering snail infection rates as well as curbing the disease cycle over time [60].

\section{TOXOPLASMA GONDII}

Toxoplasma gondii is one of the most common human zoonoses. The parasite can infect most genera of warm-blooded animals and is estimated to infect $30-50 \%$ of the human population globally [66]. The main factors associated with the great variability in the distribution of $T$. gondii infection are socioeconomic, environmental, and cultural, as well as living and eating habits [67].

Indonesia has a tropical climate, providing suitable conditions for gardening and farming, and thus increasing human contact with soil and livestock, as well as providing the possibility of contact with raw meat. Additionally, it is common to consume goat, sheep, beef, chicken, and rabbit satay, potentially as undercooked meat accompanied by raw vegetables [68].

The prevalence of $T$. gondii in Indonesia, one of the strongly affected countries, is estimated to be around 50\% [69]. The seroprevalence of toxoplasmosis was $62.5 \%(394 / 630)$ and $67.7 \%$ (107/158) in Central Java and Yogyakarta, respectively $[69,70]$. In North Sulawesi there was also a high prevalence (58.5\%; 501/856) in humans, and 2.3\% in pigs [69]. Seroprevalence was $14.6 \%$ in pigs and $7.4 \%$ in cattle in West Java [71]. Clinically, of $64 \mathrm{HIV}$-infected patients, 21 (32.8\%) gave positive results by PCR using CSF, although circulating toxoplasma IgG was present in $77.2 \%$ of patients in 1994 [72]. Also, Lestari et al. [73] reported that 26 (8.4\%) of 311 HIV patients were diagnosed with toxoplasma chorioretinitis in 2013. More research and effort by governmental and nongovernmental authorities are required to minimize rates of infection.

\section{OTHER PARASITES}

We now list other parasites known to exist in Indonesia; in protozoa; Entamoeba histolytica, Giardia lamblia, Blastocystis hominis, Cryptosporidium sp., Cyclospora cayetanensis, Trichomonas vaginalis; in Nematodes; Trichinella spiralis, Capillaria philippinensis, Strongyloides stercoralis, Anisakis, Toxocara sp.; in Trematodes; Fasciolopsis buski, Echinostoma sp.; in Cestodes; sparganum, Echinococcus granulosus and Hymenolepis nana.

The prevalence rates of the intestinal protozoa Entamoeba histolytic, Giardia lamblia and Blastocystis hominis (Bh) were $17.9 \%(76 / 424), 4.5 \%(19 / 424)$ and $34.4 \%$ (146/424), respectively, in a rural area of Southwest Sumba, East Nusa Tenggara Province, in 2014 [43]. Yoshikawa et al. [74] reported 
that the prevalence of $B h$ infection in 2010-2012 was 29.9\% (147/492) among children in Winyapu area, Southwest Sumba. In addition, a high prevalence of $B h$ was observed in Jakarta: $72.4 \%$ in 318 HIV patients (21-40 years) and $54.7 \%$ in immunocompromised children with persistent and/or recurrent diarrhea $[75,76]$. Therefore, $B h$ is thought to be a common parasite in Indonesia, although it is considered a rare parasite in Korea.

Among coccidian protozoa, Cryptosporidium spp. was found in HIV patients with chronic diarrhea in Jakarta; most of patients (28/36) were infected with $C$. hominis and two with multiple species (C. meleagridis, C. felis, and C. parvum) [77]. Microsporidium spp. such as Encephalitozoon cuniculi genotype II (7.0\%), Enterocytozoon bieneusi (2.0\%), and Cryptosporidium spp. (2.7\%) including C. parrum and C. muris, have been detected in Orangutans $(\mathrm{n}=298)$ in Sumatra and Kalimantan [78]. Also, Cyclospora cayetanensis infection causing diarrhea has been reported among travelers returning from Indonesia. Cyclosporiasis infections have been recently reported in a Korean girl, fourteen Dutch scientists and three Polish business men who had been to Indonesia [79-81].

The prevalence rate of Trichomonas vaginalis as a sexually transmitted infection in female sex workers was $15.1 \%$ among 2,500 women from 9 provinces in 2010, and 22.6\% among 217 women from Manado in Indonesia in 2011 [82,83].

Among Nematoda, 19.5\% of 190 children and teenagers were seropositive for Trichinella spiralis in Bali in 1993 [84]. Two human cases of Capillaria philippinensis infection have been reported in Indonesia; a European tourist with travelling experience in Indonesia and a 2-year-old female in 1994 [85]. Another intestinal helminth, Strongyloides stercoralis had a low infection rate of $0.6 \%$ (4/646) in Nangapanda on Flores Island in 2015 [86]. Seropositivity for Anisakis was 11\% in inhabitants of East Java in 1996, and the seroprevalence of Toxocara canis among 158 junior high school students was 65.8\% in $2005[87,88]$.

Among the Trematoda, Fasciolopsis buski infection was reported in an 11-year-old boy who had never left Indonesia [89]. A 27\% of stool samples of 548 people in Sei Papuyu village in the Babirik sub-district was positive for F. buski egg in 1985 , this high infection rate was dramatically reduced as $1 \%$ in the same sub-district in 2012 [90,91]. Two cases of echinostomiasis in 278 stools were reported in the highlands of Papua, Indonesia [92].

Among Cestoda, an average of 3.1\% sparganosis was detect- ed serologically in Papua (2.7\%), North Sumatra (2.9\%), and Bali (6.9\%) [93]. Cystic echinococcosis (CE) caused by Echinococcus granulosus, is very rare in humans [94]. However, hydatid cysts have been identified in animals such as water buffalo, goats, sheep, pigs and Tonkean macaque monkeys. Alveolar echinococcosis (AE) caused by Echinococcus multilocularis has not been reported in Indonesia [95]. The intestinal helminth, Hymenolepis nana, had a prevalence of $0.5 \%$ (2/424) in Kalena Rongo village in Southwest Sumba [45].

The limitation of this paper is that it has not been able to provide the latest data since it was not sufficient to obtain data on the current situation of parasite infection in Indonesia. Nonetheless, this report should be useful not only to parasitologists but also to travelers and people with business in Indonesia.

\section{CONFLICT OF INTEREST}

The authors declare no conflict of interest related to this study.

\section{REFERENCES}

1. Badan Pusat Statistik. Statistik Indonesia 2018 [Internet]; [cited 2019 Jan 20]. Available from: https://www.bps.go.id/publication /2018/07/03/5a963c1ea9b0fed6497d0845/statistik-indonesia-2018.html (in Indonesian).

2. Ministry of Foreign Affairs in Republic of Korea. The Current Situation of Korean Diaspora 2017 [Internet]; [cited 2019 Jan 18]. Available from: http://www.mofa.go.kr/www/wpge/m_21507/contents. do (in Korean).

3. Ministry of Justice in Republic of Korea. Korea Immigration Service Statistics 2017 [Internet]; [cited 2019 Jan 18]. Available from: http://www.immigration.go.kr/immigration/1570/subview.do?enc=Zm5jdDF8QEB8JTJGYmJzJTJGaW1 taWdyYXRpb2 4lMkYyMjglMkY0NDA2MDQIMkZhcnRjbFZpZXcuZG8IM0Y $\% 3 \mathrm{D} /$ (in Korean).

4. World Health Organization. Malaria [Internet]; [cited 2019 Jan 10]. Available from: http://www.who.int/mediacentre/factsheets/ fs094/en/.

5. Sitohang V, Sariwati E, Fajariyani SB, Hwang D, Kurnia B, Hapsari RK, Laihad FJ, Sumiwi ME, Pronyk P, Hawley WA. Malaria elimination in Indonesia: halfway there. Lancet Glob Health 2018; 6: 604-606.

6. Suwonkerd W, Ritthison W, Ngo CT, Tainchum K, Bangs MJ, Chareonviriyaphap T. Vector biology and malaria transmission in Southeast Asia. In Manguin S ed, Anopheles Mosquitoes New Insights into Malaria Vectors. Rijeka, Croatia. InTech. 2013, pp 273-325. 
7. Kementerian Kesehatan Republik Indonesia. Pedoman Manajemen Malaria. Jakarta, Indonesia. Kementerian Kesehatan Republik Indonesia. 2015 (in Indonesian).

8. Elyazar IR, Hay SI, Baird JK. Malaria distribution, prevalence, drug resistance and control in Indonesia. Adv Parasitol 2011; 74: 41-175.

9. Berens-Riha N. Plasmodium knowlesi found in several samples from Indonesia. ProMED 2009 Jun 21. http://www.promedmail.org, archieve no. 20090621. 2278

10. Kementerian Kesehatan Republik Indonesia. Profil Kesehatan Indonesia Tahun 2016. Jakarta, Indonesia. Kementerian Kesehatan Republik Indonesia. 2017 (in Indonesian).

11. Surjadjaja C, Surya A, Baird JK. Epidemiology of Plasmodium vivax in Indonesia. Am J Trop Med Hyg 2016; 95 (suppl): 121132.

12. Kementerian Kesehatan Republik Indonesia. InfoDATIN Malaria. Jakarta, Indonesia. Kementerian Kesehatan Republik Indonesia. 2016 (in Indonesian).

13. Dellicour S, Tatem AJ, Guerra CA, Snow RW, ter Kuile FO. Quantifying the number of pregnancies at risk of malaria in 2007: a demographic study. PLoS Med 2010; 7: e1000221.

14. World Health Organization. Malaria Elimination: A Field Manual for Low and Moderate Endemic Countries. Geneva, Switzerland. World Health Organization. 2007.

15. Kementerian Kesehatan Republik Indonesia. Inilah Fakta Keberhasilan Pengendalian Malaria [Internet]; [cited 2019 Jan 25]. Available from: http://www.depkes.go.id/article/view/16050200003/ inilah-fakta-keberhasilan-pengendalian-malaria.html (in Indonesian).

16. Kementerian Kesehatan Republik Indonesia. Situasi Terkini Perkembangan Program Pengendalian Malaria di Indonesia Tahun 2016 [Internet]; [cited 2019 Jan 25]. Available from: https:// drive.google.com/file/d/0BxNNPzsAPw_gWTBQZ3kyR3dqVG8/ view (in Indonesian).

17. Antara News. Malaria remains endemic in Indonesia [Internet]; [cited 2019 Jan 25]. Available from: https://en.antaranews.com/ news/110978/malaria-remains-endemic-in-indonesia/.

18. Battle KE, Karhunen MS, Bhatt S, Gething PW, Howes RE, Golding N, van Boeckel TP, Messina JP, Shanks GD, Smith DL, Baird JK, Hay SI. Geographical variation in Plasmodium vivax relapse. Malar J 2014; 13: 144.

19. Hill E, Amatuzio DS. Southwest Pacific vivax malaria: clinical features and observations concerning duration of clinical activity. Am J Trop Med Hyg 1949; 29: 203-214.

20. WHO Malaria Policy Advisory Committee and Secretariat. Malaria Policy Advisory Committee to the WHO: conclusions and recommendations of seventh biannual meeting (March 2015). Malar J 2015; 14: 295.

21. World Health Organization. Guidelines for the Treatment of Malaria. 3rd ed. Geneva, Switzerland. World Health Organization. 2015.

22. Ottesen EA, Duke BO, Karam M, Behbehani K. Strategies and tools for the control/elimination of lymphatic filariasis. Bull
World Health Organ 1997; 75: 491-503.

23. Goldman AS, Guisinger VH, Aikins M, Amarillo ML, Belizario VY, Garshong B, Gyapong J, Kabali C, Kamal HA, Kanjilal S, Kyelem D, Lizardo J, Malecela M, Mubyazi G, Nitièma PA, Ramzy RM, Streit TG, Wallace A, Brady MA, Rheingans R, Ottesen EA, Haddix AC. National mass drug administration costs for lymphatic filariasis elimination. PLoS Negl Trop Dis 2007; 1: e67.

24. Ottesen EA, Hooper PJ, Bradley M, Biswas G. The global programme to eliminate lymphatic filariasis: health impact after 8 years. PLoS Negl Trop Dis 2008; 2: e317.

25. Okon OE, Iboh CI, Opara KN. Bancroftian filariasis among the Mbembe people of Cross River state, Nigeria. J Vector Borne Dis 2010; 47: 91-96.

26. Arsin, AA. Epidemiologi Filariasis di Indonesia. Makassar, Indonesia. Masagena Press. 2016 (in Indonesian).

27. Kementerian Kesehatan Republik Indonesia. InfoDATIN Menuju Indonesia Bebas Filariasis. Jakarta, Indonesia. Kementerian Kesehatan Republik Indonesia. 2018 (in Indonesian).

28. Supali T, Djuardi Y, Lomiga A, Nur Linda S, Iskandar E, Goss CW, Miller JP, Weil GJ, Fischer PU. Comparison of the impact of annual and semiannual Mass Drug Administration on lymphatic filariasis prevalence in Flores Island, Indonesia. Am J Trop Med Hyg 2019; 100: 336-343.

29. Fischer P, Supali T, Maizels RM. Lymphatic filariasis and Brugia timori: prospects for elimination. Trends Parasitol 2004; 20: 351355.

30. World Health Organization. Progress Report 2000-2009 and Strategic Plan 2010-2020 of the Global Programme to Eliminate Lymphatic Filariasis: Halfway towards Eliminating Lymphatic Filariasis. Geneva, Switzerland. World Health Organization. 2010.

31. World Health Organization. Global Programme to Eliminate Lymphatic Filariasis: a Handbook for National Elimination Programme. Geneva, Switzerland. World Health Organization. 2013.

32. Michael E, Malecela-Lazaro MN, Simonsen PE, Pedersen EM, Barker G, Kumar A, Kazura JW. Mathematical modelling and the control of lymphatic filariasis. Lancet Infect Dis 2004; 4: 223234.

33. Ngui R, Lim YAL, Kin LC, Chuen CS, Jaffar S. Association between anaemia, iron deficiency anaemia, neglected parasitic infections and socioeconomic factors in rural children of West Malaysia. PLoS Negl Trop Dis 2012; 6: e1550.

34. Hotez PJ, Bottazzi ME, Strych U, Chang LY, Lim YAL, Goodenow MM, Abu Bakar S. Neglected tropical diseases among the Association of Southeast Asian Nations (ASEAN): overview and update. PLoS Negl Trop Dis 2015; 9: e0003575.

35. World Health Organization. Neglected tropical diseases [Internet]; [cited 2019 Jan 06]. Available from: https://www.who.int/ neglected_diseases/diseases/en/.

36. Bethony J, Brooker S, Albonico M, Geiger SM, Loukas A, Diemert D, Hotez PJ. Soil-transmitted helminth infections: ascariasis, trichuriasis, and hookworm. Lancet 2006; 367: 1521-1532.

37. Pullan RL, Smith JL, Jasrasaria R, Brooker SJ. Global numbers of 
infection and disease burden of soil transmitted helminth infections in 2010. Parasit Vectors 2014; 7: 37.

38. DataBank World Development Indicators. Poverty headcount at $\$ 3.20$ a day (PPP) (\% of population) [Internet]; [cited 2019 Jan 06]. Available from https://data.worldbank.org/indicator/SI. POV.LMIC?+ locations=ID\&locations=ID/.

39. Kementerian Kesehatan Republik Indonesia. Pencapaian Kegiatan Pengendalian Penyakit dan Penyehatan Lingkungan di dalam Profil Pemberantasan Penyakit Menular dan Penyehatan Lingkungan 2008. Jakarta, Indonesia. Kementerian Kesehatan Republik Indonesia. 2009 (in Indonesian).

40. Hotez PJ, Ehrenberg JP. Escalating the global fight against neglected tropical diseases through interventions in the Asia Pacific region. Adv Parasitol 2010; 72: 31-53.

41. Kementerian Kesehatan Republik Indonesia. Pedoman Pengendalian Kecacingan. Jakarta, Indonesia. Kementerian Kesehatan Republik Indonesia. 2012 (in Indonesian).

42. Altiara S. Hubungan sanitasi lingkungan rumah dengan kejadian cacingan pada balita di RW 03 kelurahan Panggung Kota Tegal Tahun 2010 [master's thesis]. Semarang: University of Negeri Semarang; 2011 (in Indonesian).

43. World Health Organization. Neglected tropical diseases, PCT databank, soil-transmitted helminthiases [Internet]; [cited 2019 Jan 06]. Available from: http://www.who.int/neglected_diseases/ preventive_chemotherapy/sth/en/.

44. Dinas Kesehatan Provinsi Nusa Tenggara Timur. Profil Kesehatan Provinsi Nusa Tenggara Timur Tahun 2012. NTT, Indonesia. Dinas Kesehatan Provinsi Nusa Tenggara Timur. 2013 (in Indonesian).

45. Sungkar S, Pohan AP, Ramadani A, Albar N, Azizah F, Nugraha AR, Wiria AE. Heavy burden of intestinal parasite infections in Kalena Rongo village, a rural area in South West Sumba, eastern part of Indonesia: a cross sectional study. BMC Public Health 2015; $15: 1296$.

46. World Health Organization. Intestinal worms strategy [Internet]; [cited 2019 Jan 06]. Available from: http://www.who.int/intestinal_worms/strategy/en/.

47. Sungkar S, Ridwan AS, Kusumowidagdo G. The effect of deworming using triple-dose albendazole on nutritional status of children in Perobatang village, Southwest Sumba, Indonesia. J Parasitol Res 2017; 2017: 5476739.

48. Badan Pusat Statistik. Kewarganegaraan, Suku Bangsa, Agama, dan Bahasa Sehari-hari Penduduk Indonesia Hasil Sensus Penduduk 2010 [Internet]; [cited 2019 Jan 10]. Available from: https://sp2010.bps.go.id/files/ebook/kewarganegaraan\%20penduduk\%20indonesia/index.html (in Indonesian).

49. Wandra T, Ito A, Swastika K, Dharmawan NS, Sako Y, Okamoto M. Taeniases and cysticercosis in Indonesia: past and present situations. Parasitology 2013; 140: 1608-1616.

50. Zein U, Siregar S, Janis I, Pane AH, Purba JM, Sardjono TW, Wandra T, Swastika K, Lim H, Yanagida T, Okamoto M, Ito A. Identification of a previously unidentified endemic region for taeniasis in North Sumatra, Indonesia. Acta Trop 2019; 189: 114-116.
51. Wandra T, Margono SS, Gafar MS, Saragih JM, Sutisna P, Sudewi R, Depary AA, Yulfi H, Darla DD, Okamoto M, Sato MO, Sako Y, Nakao M, Nakaya K, Craig PS, Ito A. Current situation of taeniasis and cysticercosis in Indonesia. Trop Med Health 2007; 35: 323-328.

52. Wandra T, Swastika K, Dharmawan NS, Purba IE, Sudarmaja IM, Yoshida T, Sako Y, Okamoto M, Eka Diarthini NL, Sri Laksemi DA, Yanagida T, Nakao M, Ito A. The present situation and towards the prevention and control of neurocysticercosis on the tropical island, Bali, Indonesia. Parasit Vectors 2015; 8: 148.

53. Wu HW, Ito A, Ai L, Zhou XN, Acosta LP, Lee Willingham A III. Cysticercosis/taeniasis endemicity in Southeast Asia: current status and control measures. Acta Trop 2017; 165: 121-132.

54. Swastika K, Wandra T, Dharmawan NS, Sudarmaja IM, Saragih JM, Diarthini LPE, Ariwati L, Damayanti PAA, Laksemi DAAS, Kapti N, Sutisna P, Yanagida T, Ito A. Taeniasis caused by Taenia saginata in Gianyar town and Taenia solium in Karangasem villages of Bali, Indonesia, 2011-2016: How to detect tapeworm carriers, anamnesis or microscopy?. Acta Trop 2017; 174: 19-23.

55. Salim L, Ang A, Handali S, Tsang VC. Seroepidemiologic survey of cysticercosis-taeniasis in four central highland districts of Papua, Indonesia. Am J Trop Med Hyg 2009; 80: 384-388.

56. Subahar R, Hamid A, Purba W, Wandra T, Karma C, Sako Y, Margono SS, Craig PS, Ito A. Taenia solium infection in Irian Jaya (West Papua), Indonesia: a pilot serological survey of human and porcine cysticercosis in Jayawijaya District. Trans R Soc Trop Med Hyg 2001; 95: 388-390.

57. Ito A, Putra MI, Subahar R, Sato MO, Okamoto M, Sako Y, Nakao M, Yamasaki H, Nakaya K, Craig PS, Margono SS. Dogs as alternative intermediate hosts of Taenia solium in Papua (Irian Jaya), Indonesia confirmed by highly specific ELISA and immunoblot using native and recombinant antigens and mitochondrial DNA analysis. J Helminthol 2002; 76: 311-314.

58. Margono SS, Wandra T, Swasono MF, Murni S, Craig PS, Ito A. Taeniasis/cysticercosis in Papua (Irian Jaya), Indonesia. Parasitol Int 2006; 55 (suppl): 143-148.

59. Brug SL, Tesch JW. Parasitaire wormen aan het Celebes meer (Oa. Paloe Celebes). Geneeskd. Geneeskd Tijdschr Ned Indie 1937; 82: 21-36 (in Dutch).

60. Satrija F, Ridwan Y, Jastal, Samarang, Rauf A. Current status of schistosomiasis in Indonesia. Acta Trop 2015; 141: 349-353.

61. Oemijati S. Prevalence and distribution of schistosomiasis in Indonesia: a review. Southeast Asian J Trop Med Public Health 1976; 7: 144-148.

62. Carney WP, Van Peenen PF, Sudomo M. A mammalian reservoir of Schistosoma japonicum in the Napu Valley, Central Sulawesi, Indonesia. J Parasitol 1978; 64: 1138-1139.

63. Effendi, Endah N, Herry A. Survei schistosomiasis pada hewan di Lembah Napu, Kecamatan Lore Utara Kabupaten Poso, Sulawesi Tengah. In Perkumpulan Pemberantasan Penyakit Parasit Indonesia ed, Seminar Parasitologi Nasional VI dan Kongres Perkumpulan Pemberantasan Penyakit Parasit Indonesia. Surabaya, Indonesia. Parasitologi FK UNAIR. 1989 (in Indonesian). 
64. Directorate of Vector Borne Disease Control, Directorate General of CDC, Ministry of Health, Indonesia. Assessment Report- Subdirectorate of filariasis and schistosomiasis. 1998.

65. Kementerian Kesehatan Republik Indonesia. Peraturan Menteri Kesehatan Republik Indonesia No. 19 Tahun 2018 tentang penyelenggaraan eradikasi demam keong [Internet]; [cited 2019 Jan 06]. Available from: http://ditjenpp.kemenkumham.go.id/ arsip/bn/2018/bn982-2018. pdf (in Indonesian).

66. Flegr J, Prandota J, Sovičková M, Israili ZH. Toxoplasmosis - a global threat. Correlation of latent toxoplasmosis with specific disease burden in a set of 88 countries. PLoS One 2014; 9: e90203.

67. Saadatnia G, Golkar M. A review on human toxoplasmosis. Scand J Infect Dis 2012; 44: 805-814.

68. Retmanasari A, Widartono BS, Wijayanti MA, Artama WT. Prevalence and risk factors for toxoplasmosis in Middle Java, Indonesia. Ecohealth 2017; 14: 162-170.

69. Tuda J, Adiani S, Ichikawa-Seki M, Umeda K, Nishikawa Y. Seroprevalence of Toxoplasma gondii in humans and pigs in North Sulawesi, Indonesia. Parasitol Int 2017; 66: 615-618.

70. Muflikhah ND, Supargiyono, Artama WT. Seroprevalence and risk factor of toxoplasmosis in schizophrenia patients referred to Grhasia Psychiatric Hospital, Yogyakarta, Indonesia. Afr J Infect Dis 2018; 12 (suppl): 76-82.

71. Ichikawa-Seki M, Guswanto A, Allamanda P, Mariamah ES, Wibowo PE, Igarashi I, Nishikawa Y. Seroprevalence of antibody to TgGRA7 antigen of Toxoplasma gondii in livestock animals from Western Java, Indonesia. Parasitol Int 2015; 64: 484-486.

72. Ganiem AR, Dian S, Indriati A, Chaidir L, Wisaksana R, Sturm P, Melchers W, van der Ven A, Parwati I, van Crevel R. Cerebral toxoplasmosis mimicking subacute meningitis in HIV-infected patients; a cohort study from Indonesia. PLoS Negl Trop Dis 2013; 7: e1994.

73. Lestari YD, Sitompul R, Edwar L, Djoerban Z. Ocular diseases among HIV/AIDS patients in Jakarta, Indonesia. Southeast Asian J Trop Med Public Health 2013; 44: 62-71.

74. Yoshikawa H, Tokoro M, Nagamoto T, Arayama S, Asih PB, Rozi IE, Syafruddin D. Molecular survey of Blastocystis sp. from humans and associated animals in an Indonesian community with poor hygiene. Parasitol Int 2016; 65: 780-784.

75. Kurniawan A, Karyadi T, Dwintasari SW, Sari IP, Yunihastuti E, Djauzi S, Smith HV. Intestinal parasitic infections in HIV/AIDS patients presenting with diarrhoea in Jakarta, Indonesia. Trans $\mathrm{R}$ Soc Trop Med Hyg 2009; 103: 892-898.

76. Idris NS, Dwipoerwantoro PG, Kurniawan A, Said M. Intestinal parasitic infection of immunocompromised children with diarrhoea: clinical profile and therapeutic response. J Infect Dev Ctries 2010; 4: 309-317.

77. Kurniawan A, Dwintasari SW, Connelly L, Nichols RA, Yunihastuti E, Karyadi T, Djauzi S. Cryptosporidium species from human immunodeficiency-infected patients with chronic diarrhea in Jakarta, Indonesia. Ann Epidemiol 2013; 23: 720-723.

78. Mynářová A, Foitová I, Kváč M, Květoňová D, Rost M, MorroghBernard H, Nurcahyo W, Nguyen C, Supriyadi S, Sak B. Preva- lence of Cryptosporidium spp., Enterocytozoon bieneusi, Encephalitozoon spp. and Giardia intestinalis in wild, semi-wild and captive Orangutans (Pongo abelii and Pongo pygmaeus) on Sumatra and Borneo, Indonesia. PLoS One 2016; 11: e0152771.

79. Yu JR, Sohn WM. A case of human cyclosporiasis causing traveler's diarrhea after visiting Indonesia. J Korean Med Sci 2003; 18: 738-741.

80. Blans MC, Ridwan BU, Verweij JJ, Rozenberg-Arska M, Verhoef J. Cyclosporiasis outbreak, Indonesia. Emerg Infect Dis 2005; 11: 1453-1455.

81. Bednarska M, Bajer A, Welc-Falęciak R, Pawełas A. Cyclospora cayetanensis infection in transplant traveller: a case report of outbreak. Parasit Vectors 2015; 8: 411.

82. Tanudyaya FK, Rahardjo E, Bollen LJ, Madjid N, Daili SF, Priohutomo S, Morineau G, Nurjannah, Roselinda, Anartati AS, Purnamawati KA, Mamahit ER. Prevalence of sexually transmitted infections and sexual risk behavior among female sex workers in nine provinces in Indonesia, 2005. Southeast Asian J Trop Med Public Health 2010; 41: 463-473.

83. Mawu FO, Davies SC, McKechnie M, Sedyaningsih ER, Widihastuti A, Hillman RJ. Sexually transmissible infections among female sex workers in Manado, Indonesia, using a multiplex polymerase chain reaction-based reverse line blot assay. Sex Health 2011; 8: 52-60.

84. Chomel BB, Kasten R, Adams C, Lambillotte D, Theis J, Goldsmith R, Koss J, Chioino C, Widjana DP, Sutisna P. Serosurvey of some major zoonotic infections in children and teenagers in Bali, Indonesia. Southeast Asian J Trop Med Public Health 1993; 24: 321-326.

85. Bangs MJ, Purnomo, Andersen EM. A case of capillariasis in a highland community of Irian Jaya, Indonesia. Ann Trop Med Parasitol 1994; 88: 685-687.

86. Wiria AE, Hamid F, Wammes LJ, Prasetyani MA, Dekkers OM, May L, Kaisar MM, Verweij JJ, Guigas B, Partono F, Sartono E, Supali T, Yazdanbakhsh M, Smit JW. Infection with soil-transmitted helminths is associated with increased insulin sensitivity. PLoS One 2015; 10: e0136002.

87. Uga S, Ono K, Kataoka N, Hasan H. Seroepidemiology of five major zoonotic parasite infections in inhabitants of Sidoarjo, East Java, Indonesia. Southeast Asian J Trop Med Public Health 1996; 2: 556-561.

88. Hayashi E, Tuda J, Imada M, Akao N, Fujita K. The high prevalence of asymptomatic Toxocara infection among schoolchildren in Manado, Indonesia. Southeast Asian J Trop Med Public Health 2005; 36: 1399-1406.

89. Hadidjaja P, Dahri HM, Roesin R, Margono SS, Djalins J, Hanafiah M. First autochthonous case of Fasciolopsis buski infection in Indonesia. Am J Trop Med Hyg 1982; 31: 1065.

90. Handoyo I, Ismuljowono B, Darwis F, Rudiansyah. Further survey of fasciolopsiasis in Babirik subdistrict, Hulu Sungai Utara Recency, South Kalimantan province. Trop Biomed 1986; 3: 119123.

91. Dinas Kesehatan Kabupaten Hulu Sungai Utara. Profil kesehat- 
an kabupaten Hulu Sungai Utara tahun 2012 [Internet]; [cited 2019 Jan 07]. Available from: http://www.depkes.go.id/resources/download/profil/PROFIL_KAB_KOTA_2012/6308_Kalsel_ Kab_Hulu_Sungai_Utara_2012.pdf (in Indonesian).

92. Bangs MJ, Purnomo, Anthony RL. Echinostomiasis in the highlands of Irian Jaya, Indonesia. Ann Trop Med Parasitol 1993; 87: 417-419.

93. Margono SS, Sutjahyono RW, Kurniawan A, Nakao M, Mulyani T,
Wandra T, Ito A. Diphyllobothriasis and sparganosis in Indonesia. Trop Med Health 2007; 35: 301-305.

94. Margono SS, Abdullah AA, Himawan S, Dharmawan NS, Wandra T. Notes on Echinococcus and echinococcosis in Indonesia. Asian Parasitol 2005; 2: 251-257.

95. Ito A, Budke CM. The echinococcoses in Asia: the present situation. Acta Trop 2017; 176: 11-21. 
